\title{
PRŌBA CHRYSTIANIZACJI LITWY W CZASACH GIEDYMINA
}

$\mathrm{Na}$ próby chrystianizacji Litwy, podejmowane szereg razy od czasów Mendoga po czasy Jagiełły, a więc w przeciągu ponad 130 lat, patrzymy zwykle pod kątem widzenia zabiegów idących z zewnątrz: ze strony Zakonu Niemieckiego, biskupstwa czy arcybiskupstwa ryskiego, Polski, Kościoła prawosławnego na Rusi, misjonarzy dominikańskich i franciszkańskich, wreszcie miasta Rygi. Traktujemy więc Litwę jako przedmiot rozmaitych usiłowań zewnętrznych, rzadziej natomiast wnikamy w motywacje samych Litwinów, jako podmiot ich własnych dziejów. Motywacje te zwykliśmy sprowadzać do rachub politycznych i zagrożeń z zewnątrz. Wydaje się to zrozumiałe, skoro z reguły jesteśmy zdani na przekazy źródłowe obce, które nie dostrzegały czynników wewnętrznych, a zatem narzucały nam ów przedmiotowy sposób widzenia Litwy pogańskiej.

Z drugiej strony jesteśmy przeświadczeni, że Litwa miała swój bogaty świat wierzeń i wyobrażeń religijnych, głęboko zakorzenionych w świadomości jej mieszkańców, które stanowiły mocną zaporę dla chrystianizacji ${ }^{1}$. Nosicielem tych wierzeń i wyobrażeń był nie tylko lud, ale była nim litewska elita władzy, były nim także rodziny książęce. Trzeba wszakże przyjąć, że ekspansywność Litwy, datująca się przynajmniej od czasów Mendoga, jej wchodzenie na obszary schrystianizowane już w obrządku wschodnim, dawały Litwinom możliwość kontaktu ze światem innych wartości. Rozszerzały ich horyzonty, a zarazem znieczulały na odmienności kulturowe. Koligacenie się elit litewskich z elitami ziem ruskich było mocnym czynnikiem przezwyciężania tradycjonalizmów. Konserwatywne i najsilniej przywiązane do własnych wierzeń były masy, choć i ich liczni przedstawiciele podlegali w toku wypraw wojennych obcym wpływom kulturowym. Długie trwanie Litwy w otoczeniu chrześcijańskim pro-

* W przypisach zastosowanı następujące skróty tytułów wydawnictw źródlowych:

LEC

- Liv-, Est- und Curländisches Urkundenbuch, wyd. F. G. Bunge, t. 2-6, Reval-Ryga 1855-1873.

PreussUb- Preussisches Urkundenbuch, wyd. M. Hein, E. Maschke, t. 2, Königsberg Pr. 1932.

Theiner - Vetera monumenta Poloniae et Lithuaniae, wyd. A. Theiner, t. 1, Romae 1860.

${ }_{1}^{1}$ Por. A. Brückner, Starożytna Litwa. Ludy $i$ bogi. Szkice historyczne $i$ mitologiczne, Olsztyn 1979. 
wadziło i musiało prowadzić do powolnej erozji kultury tradycyjnej. Nie może też dziwić, że bardziej izolowana Żmudź znacznie dłużej trwała $\mathrm{w}$ pogaństwie.

Tak, z grubsza rzecz biorąc, musiał wyglądać ów proces przybliżania się państwa litewskiego do chrześcijaństwa, zanim bariera została ostatecznie przełamana. W tym długim łańcuchu na uwagę zasługuje każde ogniwo i każde było już przedmiotem naukowej eksploracji. Pod jednym względem wszakże wyróżnia się próba chrystianizacji Litwy w czasach Giedymina, kulminująca $w$ latach 1323-1324. Jest ona mianowicie stosunkowo dobrze oświetlona materiałem źródłowym, co prawda jednorodnym, bo składa się nań szereg wymienionych wówczas listów, w tym także parę pisanych w imieniu Giedymina. Materiał ten pozwala oczywiście odtworzyć przebieg całej sprawy i rozpoznać poszczególne jej elementy. Pod tym względem był zresztą wielokrotnie wykorzystywany. Nauka polska od dłuższego czasu już do niego nie powraca, jak gdyby stał się zamkniętą kartą. Trzeba jednakże od razu stwierdzić, że sprawa owych listów jest kontrowersyjna, a pytanie, jakie się z nimi wiąże, dotyczy ich autentyczności. Stanowisko naszej historiografii na ten temat było od dawna jednoznaczne, tzn. były one w jej ocenie autentyczne. Za ostatnie słowo uchodziła ogłoszona jeszcze w 1895 r. praca Antoniego Prochaski: $O$ prawdziwości listów Giedymina, tym bardziej że pogląd tego autora podzielali tacy badacze, jak Kazimierz Chodynicki i Władysław Abraham ${ }^{2}$. Aprobowała go również historiografia litewska ${ }^{3}$. W historiografii niemieckiej natomiast już Johannes Voigt uważał te listy za falsyfikaty, a nowsze badania historyków niemieckich stanowisko takie ugruntowały. Należy tu wspomnieć dwu badaczy, z których jeden, Kurt Forstreuter, kwestionuje autentyczność ich wszystkich, a drugi, Herbert Spliet, opowiada się za powstaniem w drodze fałszerstwa tylko niektórych spośród nich. Poglądy ich, wypowiedziane jeszcze przed wojną, zostały przez obu potwierdzone w publikacjach powojennych ${ }^{4}$.

Rysuje się więc dziś od nowa problem autentyczności listów Giedy-

2 A. Prochaska, O prawdziwości listów Gedymina, [w:] Rozprawy AU. Wydział Historyczno-Filozoficzny, t. 32, Kraków 1896, s. 222-255; K. Chodynicki, Próby zaprowadzenia chrześcijaństwa na Litwie przed r. 1386, „Przegląd Historyczny" 18 (1914) s. 266; W. A b raham, Powstanie organizacji Kościota lacińskiego na Rusi, Lwów 1904, s. 184 przypis 2; t e nże, Polska a chrzest Litwy, [w:] Polska $i$ Litwa w dziejowym stosunku, Kraków 1914, s. 8 przypis 4.

${ }_{8}$ Por. K. A vižonis, Die Entstehung und Entwicklung des litauischen Adels bis zur litauisch-polnischen Union 1385, Berlin 1932 (Historische Studien, Heft 223), s. $87-88$ przypis 43 .

${ }_{4} \mathrm{~K}$. Forstreuter, Die Bekehrung Gedimins und der Deutsche Orden, „Altpreussische Forschungen” 5 (1928); toż wzmowione w: „Jahrbuch der Albertus Universität zu Königsberg/Pr." 6 (1955), oraz w tomie tegoż autora: Deutschland und Litauen im Mittelalter, Köln-Gratz 1962; H. Spliet, Die Briefe Gedimins. Ein Beitrag zu der Geschichte der Stadt Riga, Sinsheim 1953 (pierwotna wersja tej pracy pokazała się w r. 1939, a następnie była wznawiana z uzupełnieniami w r. $1940 / 41$ i 1944). 
mina, który musi być tu zasygnalizowany. Zasadza się on głównie na tym, że żaden $\mathrm{z}$ owych listów nie zachował się $\mathrm{w}$ oryginale, że wątpliwości budzi ich sekwencja, że miejscami nieprawdopodobna wydaje się ich treść, że wreszcie można wskazać na okoliczności, które wydają się kłócić z ich istotą. Nie da się wszakże tych listów oderwać od całego, zakrojonego na dużą skalę planu chrystianizacyjnego, w który w każdym razie, obok innych czynników, zaangażowana była Stolica Apostolska. Sprawę autentyczności tych listów można by sprowadzić do pytania, czy da się w ogóle pomyśleć, aby cały ów plan chrystianizacji Litwy powstał poza plecami tak przedsiębiorczego i aktywnego władcy, jakim był Giedymin, dodajmy - bez jego wiedzy i zgody. Wszystkie zatem wątpliwości, jakie korespondencja ta nasuwa, można starać się wyjaśnić tak samo dobrze przy założeniu, że jest ona autentyczna, jak też — że autentyczna nie jest. Żaden z przytoczonych argumentów przeciwko autentyczności niezbity nie jest. Podzielając wątpliwości zgłoszone już w literaturze przedmiotu, przypomnę ów ważny dziejowo epizod starań o chrystianizację Litwy w sekwencji zachowanych przekazów źródłowych i z całą ostrożnością, jakiej przekazy te wymagają.

\section{I}

Panowanie Giedymina przypada na lata 1315-1341 i stanowi epokę w dziejach Litwy. Był bowiem Giedymin drugim po Mendogu wielkim organizatorem państwa litewskiego. W jego życiu i działaniu wiele jest elementów niejasnych. Wątpliwości wywołuje już jego pochodzenie. Według kroniki pruskiej Pawła Pole’a był on koniuszym (Pferdemarschalk) swego poprzednika na książęcym tronie, Witenesa, po którym - jak można stąd domniemywać - uzurpował sobie władzę ${ }^{\mathbf{5}}$. Prawdopodobnie w oparciu o to źródło jedna z redakcji Rocznika oliwskiego informuje, że ów koniuszy (magister stabuli apud Witenem) imieniem Gediminus, człowiek ambitny i wyniosłego ducha, zabił swojego pana w zmowie z jego żoną i wraz z nią przejął wielkie księstwo ${ }^{6}$. Wiadomość tę powtórzył Jan Długosz ${ }^{7}$, a za nim późniejsi historiografowie, jak Maciej z Miechowa, Marcin Kromer, Marcin Bielski i Maciej Stryjkowski. Tradycja litewska uczyniła Giedymina synem Witenesa ${ }^{8}$. Wreszcie źródło współczesne Giedyminowi, adresowany do niego list rajców Rygi z 1322 r., wyrażając nadzieję utrzymania z nim dobrych sto-

5 Scriptores rerum Prussicarum, t. 5 s. 223.

${ }^{6}$ Cytuje J. Wolff, Ród Giedymina, Lwów 1886, s. 3 przypis 1.

7 J. Długosz, Annales seu cronicae incliti Regni Poloniae, lib. X, Warszawa 1985 , s. 92.

${ }^{8} \mathrm{~K}$. Chodynicki, Geneza dynastii Giedymina, „Kwartalnik Historyczny” 40 (1926) s. $541-566$. 
sunków, odwołuje się do tych, jakie utrzymywał z nimi jego „brat” i poprzednik Witenes ${ }^{9}$. Można by wobec tego wiarygodnego świadectwa pominąc milczeniem inne, gdyby nie okoliczność, że termin „brat” (frater) był w źródłach średniowiecznych wieloznaczny. W każdym razie nie należy on wyłącznie do terminologii genealogicznej, a zatem nie oznacza tylko związku pokrewieństwa, wynikającego $\mathrm{z}$ urodzenia ze wspólnych rodziców lub wspólnego rodzica ${ }^{10}$.

Stosunkowo dobrze znamy politykę zewnętrzną Giedymina. Znalazła ona bowiem odbicie w źródłach obcych: ruskich, polskich, zakonnych i innych ${ }^{11}$. Polityka ta znaczy się dużą ekspansywnością państwa litewskiego, które mając za punkt wyjścia Auksztotę czyli Litwę właściwą, oraz Żmudź i zajętą przez poprzedników Ruś Czarną z Grodnem, miało urosnąć w ciągu dwu generacji panujących litewskich do ogromnych rozmiarów. W 1318 r. syn Giedymina Olgierd został ożeniony z córką księcia witebskiego Jarosława. Gdy ten zmarł w dwa lata później, Litwa weszła w posiadanie jego księstwa. Udało się Giedyminowi zawładnąc Pskowem, gdzie osadził swego namiestnika. Skutecznie przeprowadzona przez tegoż wyprawa przeciw inflanckiemu odłamowi państwa zakonnego sprawiła, że w 1323 r. został w Pskowie uznany księciem. Na trudności natrafił Giedymin w Nowogrodzie Wielkim, który właśnie w 1323 r. sprzymierzył się przeciw Litwie z Zakonem. W tym samym czasie, w l. 1323-1324, zawładnęła Litwa Podlasiem w bezpośrednim sąsiedztwie z Polską. Równocześnie podjął Giedymin szereg wysiłków zmierzających do przejmowania ziem ruskich $\mathrm{z}$ rąk tatarskich. Ułatwiała mu to niepopularność ,,jarzma tatarskiego", które chętnie zamieniano na mniej uciążliwą zwierzchność litewską. Okolicznością sprzyjającą było daleko posunięte rozdrobnienie polityczne Rusi. Jakkolwiek polityka ta stawiała Litwę zarówno w stan konfliktu ze Złotą Ordą, jak też z księstwem moskiewskim, które pod panowaniem Iwana Kality (1325-1340) wystąpiło z programem ,zbierania ziem ruskich", to przecież przyniosła niezwykłe sukcesy. Pod władze Litwy dostała się w krótkim czasie znaczna część Rusi Białej, gdzieś po środkowy Dniepr.

W r. 1321, lub najpóźniej w 1322, doszło do małżeństwa córki Giedymina Elżbiety z księciem płockim Wacławem (Wańką) ${ }^{12}$. Wchodząc w r. 1323 na Podlasie, nie przeszkodził Giedymin Łokietkowi we wprowadzeniu

9 LEC 6 nr 3068.

10 Por. B. Wy rozum k a, Terminologia pokrewieństw i powinowactw, „Rocznik Lubelski" 23/24 (1981-1982) s. 35-45.

11 A. Prochaska, Stosunki Krzyżaków z Giedyminem $i$ Łokietkiem, „Kwartalnik Historyczny" 10 (1896) s. 1-66; S. Z a jąc zkow ski, W sprawie zajęcia Podlasia przez Giedymina, „Ateneum Wileńskie” 6 (1929) s. 1-7; te n że, Dzieje Litwy pogańskiej do 1386 r., Lwów 1930, rozdz. IV.

12 O. B a lzer, Genealogia Piastów, Kraków 1895, s. 444-446. W. D w o r z ac z ek, Genealogia, Warszawa 1959, tabl. 4. 
na tron halicko-włodzimierski księcia mazowieckiego Bolesława Trojdenowica. Nie można wyłączyć tu nawet pewnego porozumienia. Doszło do niego na pewno w r. 1325, kiedy to córka Giedymina Aldona została wydana za Kazimierza Wielkiego ${ }^{13}$. Powstał wówczas sojusz, który zaszachował skutecznie państwo zakonne, a zaowocował w wyprawie Łokietka w 1326 r. z udziałem Litwy przeciw Brandenburgii. Sojusz ten trwał przynajmniej do 1330 r., a dopiero 10 lat później miała się zderzyć polityka litewska $\mathrm{z}$ polską na terenie Rusi halicko-włodzimierskiej ${ }^{14}$.

Mniej możemy powiedzieć o polityce wewnętrznej Giedymina, choć pewne jej trendy są widoczne. Starał się otworzyć Litwę na kontakty handlowe z Rygą, Pskowem, a zapewne również z Nowogrodem Wielkim. Zabiegał o osadników, w tym zwłaszcza o kupców i rzemieślników. Tradycja i legenda łączą z nim założenie Wilna. Był na pewno władcą tolerancyjnym, bo nie odżegnywał się od wpływów wschodnich; miał równocześnie w swoim otoczeniu franciszkanów i zezwalał na budowę kościołów. Wiele wysiłków musiał poświęcić na integrowanie swego państwa, rozległego już i zróżnicowanego pod względem wierzeń, kultury i obyczaju.

\section{II}

Pierwsze próby chrystianizacji Litwy w czasach Giedymina wyszły z zewnątrz, a znalazły odbicie w bulli Jana XXII z 3 lutego 1317 r. ${ }^{15}$ Nie wiemy, $z$ czyjej inicjatywy $i$ inspiracji bulla ta się narodziła, nie znamy odzewu, jaki wywołała. Jest jedna poszlaka, która mogłaby wskazywać na zabiegi $\mathrm{w}$ tej sprawie ze strony Polski, a mianowicie to, że bulla ta została wystawiona pod tą samą datą dzienną, co inna bulla, dotycząca biskupstwa płockiego ${ }^{16}$. Jest to jednak za mało, aby stwierdzić czy nawet się domyślać, że to Kościół polski lub Władysław Łokietek był promotorem tej sprawy. Bulla jest wszakże ciekawa sama w sobie, albowiem pozwala nam wejrzeć w te środki perswazji, których używała wówczas Stolica Apostolska. Otóż argumentacja pozostawała wyłącznie na gruncie religii. Nie widać tu ani szantażu, ani nacisku politycznego. Punktem wyjśscia jest natomiast odniesienie do sił przyrody: „Należy czcić i bać się tego, który rozkazuje wiatrom i morzu, aby nie wystąpiło ze swoich granic". Następuje wykład o grzechu pierworodnym i o śmierci, której wskutek tego grzechu nikt ujść nie może, a potem o odkupieniu doko-

$18 \mathrm{~J}$. Wyrozumski, Kazimierz Wielki, Wrocław 1985, s. 19.

14 Tamże, rozdz. IV.

15 W. Abraham, Powstanie organizacji..., dodatki nr 3 .

16 Theiner $1 \mathrm{nr}$ 212. Za związkiem bulli adresowanej do Giedymina z polityką Łokietka opowiada się K. Chodynicki, Próby..., s. 262 n. 
nanym przez Chrystusa, który w sposób cudowny narodził się z Dziewicy i dla zbawienia ludzi zmarł na krzyżu. Tak jak nikt nie jest wyłączony od skazującego wyroku potępienia, tak nikt nie zostanie zbawiony, kto nie opowie się za nim. Teraz papież przedstawia swój urząd jako pełniony w zastępstwie Chrystusa, uprasza gorąco Giedymina, aby porzucił wraz z podległymi mu ludami zastarzałe błędy grzechu oraz zaślepienia i przez sakrament chrztu przyjął uczestnictwo w łasce Bożej i w dziele zbawienia.

Przedstawiony tutaj w wielkim skrócie tekst bulli zachował się w Archiwum watykańskim, a zatem nie ma problemu jego autentyczności. Pozostaje on jednak osamotnionym świadectwem zabiegów chrystianizacyjnych, o których nic więcej powiedzieć się nie da. Dopiero najwcześniej w 1322 r. zostały podjęte nowe próby w tym zakresie. Ale mamy tu tylko pewną poszlakę. A mianowicie w dniu 29 listopada 1322 r. rajcy miasta Rygi odpowiedzieli na adresowany do nich list Giedymina, który miał na uwadze sojusz z Rygą i jej arcybiskupem, wymierzony przeciw Zakonowi. Z listu wiadomo, że Zakon podejmował wrogie działania przeciwko kupcom ryskim, a spór arcybiskupa ryskiego z Zakonem toczący się w Awinionie i dłuższa już obecność tamże metropolity ryskiego były przedmiotem szczególnego zainteresowania władcy Litwy. Z listu wszakże nie wynika, jakoby tenże składał wobec Rygi jakieś deklaracje co do przyjęcia chrześcijaństwa, ale wyłączyć tego nie można. Wyraźna wzmianka o tym, że w grę wchodziło przywrócenie między Litwą i Rygą przyjaznych stosunków, jakie łączyły je w czasach Witenesa ${ }^{17}$, wskazuje na dokonujący się zwrot w polityce Giedymina.

$\mathrm{Z}$ kolei uwagę naszą zwraca list wielkiego księcia Litwy z 25 stycznia 1323 r., adresowany do wszystkich w świecie chrześcijan, a w szczególności do miast: Lubeki, Sundu, Bremy, Magdeburga, Kolonii ,i innych aż po Rzym", w którym tenże - tytułując się jak władca chrzreścijański: Dei gratia Letphinorum Ruthenorumque rex, princeps et dux Samogitiae - zawiadamia, że wysłał posła z listem do papieża (domino apostolico patri nostro sanctissimo) i czeka jego odpowiedzi oraz jego legatów. Jeżeli przybędą, zostaną przyjęci. Pragnie dotrzymać wszystkiego, co napisał summo pontifici, ,na chwałę Boga i ku czci świętego Kościoła”. Zapowiada zakładanie kościołów, tak jak to czynił dotychczas. Wspomina kościół dominikański w Wilnie, który w ciągu dwu lat od nowa został założony, oraz dwa franciszkańskie, jeden w Wilnie, drugi w Nowogródku. Ten drugi Krzyżacy ,dla zniszczenia chrześcijaństwa i wytępienia braci mniejszych" spalili, ale Giedymin kazał go odbudować „na chwałę Boga wszechmogąceภo, jego rodzicielki Marii dziewicy i św. Franciszka..., aby

17 LEC 6 nr 3068. 
chwała Chrystusa na pożytek nasz oraz synów i żon naszych, a także wszystkich czczących prawdziwego Boga Jezusa Chrystusa, przez braci tych trwale pozostała". Dalej zapowiada, że będzie popierał biskupów, duchownych i zakonników, z wyjątkiem tych, którzy kupczą ,,jałmużną dobrych ludzi". Otwiera swoje państwo dla wszystkich ludzi dobrej woli: rycerzy, kupców, rzemieślników i innych osadników, zapewniając godne wyposażenie $\mathrm{w}$ ziemię, wolność od ceł, 10 lat wolnych od czynszów. Zainteresowanym osadnikom nadaje prawo ryskie, które ma trwać tak długo, dopóki nie zostanie wynalezione lepsze. Dokument został opatrzony pieczęcią Giedymina oraz adnotacją w formie prośby do odnośnych miast, aby został przepisany i w kopii wywieszony na drzwiach kościoła, a w oryginale wysłany do następnego miasta, na chwałę Bożą. Kończy się prośbą o modlitwę (orate Deum pro nobis) ${ }^{18}$.

Ten dokument, pisany $\mathrm{w}$ tak bardzo chrześcijańskim tonie, a zachowany tylko $\mathrm{w}$ odpisie $\mathrm{w}$ archiwum miejskim w Rydze, może budzić wątpliwości co do tego, czy jest autentyczny ${ }^{19}$. Nie może być jednak rozpatrywany $\mathrm{z}$ osobna, ale łącznie $\mathrm{z}$ innymi pismami dotyczącymi sprawy chrystianizacji Litwy za Giedymina i tylko w kontekście całej tej sprawy. Nasuwa się zatem od razu pytanie o ów list Giedymina do Stolicy Apostolskiej, na który się on $\mathrm{w}$ omówionym piśmie do miast powoływał. I od razu trzeba stwierdzić, że nie ma takiego listu w Archiwum watykańskim, co nie może być wszakże wystarczającym świadectwem przeciwko jego autentyczności. Znany jest natomiast $\mathrm{z}$ niepełnego odpisu, mniej więcej współczesnego, który znajdował się w dawnym archiwum państwowym w Królewcu. Pod względem treści całkowicie by przystawał do zaostrzonej sytuacji Litwy oraz arcybiskupa ryskiego i miasta Rygi w stosunkach z Zakonem, sytuacji, która znalazła wyraz w omówionym już liście rajców ryskich, ale z drugiej strony brak formuły datacyjnej utrudnia zajęcie jasnego stanowiska w tej sprawie. W nauce albo łączono go z grupą innych listów Giedymina z 26 maja 1323 r. ${ }^{20}$, albo odnoszono do r. 1322, stosownie do informacji z 25 stycznia 1323 r. ${ }^{21}$, albo też uważano go za falsyfikat powstały bez wiedzy i zgody Giedymina ${ }^{22}$.

Należy się przyjrzeć treści tego listu. Otóż czytamy w nim, że Giedymin już od dawna słyszał o powinności podporządkowania się wyznawców wiary chrześcijańskiej papieżowi i o zwierzchności Rzymu nad ludźmi wiary katolickiej. Pisze o nawróceniu się Mendoga, który jednak z po-

18 Tamże, nr 3069; regest $\mathrm{w}$ t. 2, PreussUb $2 \mathrm{nr} 398$.

$19 \mathrm{~W}$ nowszej historiografii kwestionuje jego autentyczność K. Forstreuter (jw.). Nie zająl natomiast takiego stanowiska H. Spliet (jw.).

20 LEC 2 nr 687 (tekst listu).

${ }_{21}$ PreussUb 2 nr 390 (regest i komentarz).

22 H. Spliet, jw.; K. Forstreuter, jw.

7 - Analecta Cracoviensia 
wodu nieprawości doznawanych od Zakonu odstąpił od Kościoła i to jest powód, dla którego Litwa pozostała „w błędzie” przodków Giedymina. Dalej mowa o próbach kontaktów pokojowych z arcybiskupem ryskim, w których Zakon przeszkadzał, zabijając posłów. Posłowie powracający od wysłannika Stolicy Apostolskiej w Inflantach jedni zostali zabici, inni powieszeni, a jeszcze innych zmuszono do tego, że się potopili. Jest tu wzmianka o staraniach Witenesa $u$ legata papieskiego $w$ Inflantach i $u$ tamtejszego arcybiskupa, aby wysłali na Litwę franciszkanów. Wybudowany dla nich kościół został przez Krzyżaków spalony. Nie pominięto tu krzywd zadanych przez Zakon arcybiskupstwu ryskiemu, co wyraźnie wskazuje na krąg, w którym - czy przy udziale którego - list powstał. Czytamy dalej o przebywających na Litwie franciszkanach i dominikanach, którzy uzyskali pełną swobodę udzielania chrztu, głoszenia kazań i odprawiania nabożeństw. I wreszcie następuje deklaracja gotowości ze strony Giedymina posłuszeństwa Stolicy Apostolskiej i przyjęcia chrześcijaństwa, byle się to nie łączyło z żadnymi powinnościami na rzecz Zakonu.

Dochodzimy teraz do grupy trzech listów noszących datę 26 maja 1323 r. Jeden $\mathrm{z}$ nich jest adresowany do prowincjałów i przełożonych zgromadzeń dominikańskich, szczególnie na terenie Saksonii, drugi analogicznie do zgromadzeń franciszkańskich, a trzeci do grupy miast, wśród których imiennie wymienione zostały: Lubeka, Rostock, Sund, Greifswald, Szczecin i ogólnie miasta Gotlandii, był zatem jak gdyby nawiązaniem do listu z 25 stycznia $1323 \mathrm{r}^{23}$ We wszystkich tych trzech listach wystawca tytułuje się na sposób chrześcijański jako ,król Litwinów i Rusinów oraz książę Żmudzi”; zachodzą tylko drobne werbalne różnice. Wszystkie trzy zachowały się $\mathrm{w}$ formie instrumentów notarialnych, zatem $\mathrm{w}$ postaci uwierzytelnionej, co w każdym razie wyłącza możliwość ich późniejszego sfabrykowania. Nadto znane są zarówno z archiwum w Królewcu, jak też $\mathrm{z}$ archiwum państwowego $\mathrm{w}$ Lubece ${ }^{24}$. Zdaniem Herberta Splieta miałyby one jednak być tekstami powielanymi poza wiedzą i zgodą Giedymina zapewne przez franciszkanów. Tym bardziej za falsyfikaty uznaje je Kurt Forstreuter.

A oto treść tych listów, niewiele różniących się między sobą, przy czym wzajemnie bliższe sobie są listy do wymienionych zgromadzeń zakonnych. Informuje w nich wystawca, iż zwrócił się osobnym pismem do Stolicy Apostolskiej, aby papież przyjął Litwinów do swojej owczarni. $\mathrm{Z}$ dnia na dzień z lękiem i troską (cum timore et taedio) wyczekuje odpowiedzi. Otrzymał już jakąś odpowiedź o rychłym przybyciu legatów, ale właśnie zwłoka rodzi w nim ów niepokój. Wynikałoby stąd, że już

23 LEC $2 \mathrm{nr} 688,689,690$.

24 PreussUb 2 nr 408, 409, 410, 414, 415. 
dość dawno do papieża się zwrócił. We wszystkich listach prosi, aby informowano świat o jego woli wejścia do społeczności chrześcijańskiej. Dominikanie mieliby to czynić w swoich kazaniach, franciszkanie przesyłając wiadomość od kościoła do kościoła, a mieszczanie od miasta do miasta. We wszystkich tekstach mowa jest o tym, że Giedymin pragnie zebrać biskupów i duchownych, z wyłączeniem jednakże takich, którzy by działali na szkodę Kościoła. W sformułowaniu dokumentu adresowanego do miast chodzi o tych: „którzy z klasztorów czynią schronisko łotrów, sprzedają jałmużnę na szkodę dusz i skąd wychodzą łotrowie z zaleceniem zabijania duchownych", co oczywiście dotyczy Krzyżaków.

We wszystkich trzech dokumentach wyrażona jest wola wystawcy ściągnięcia na Litwę rycerzy, kupców, rzemieślników, a według dokumentu adresowanego do miast także rolników. Są tu przyrzeczenia odpowiednich nadań ziemi, swobód handlowych, wolnizny od czynszów i innych płatności. Jest także zachęta w innej postaci, a mianowicie, że w królestwie Giedymina ziemia rodzi obficiej niż gdzie indziej. Jak dawniej, zapewniał i tutaj osadnikom prawo ryskie. W dokumentach adresowanych do franciszkanów i do miast została wskazana bezpieczna droga na Litwę, która miała prowadzić przez księstwo księcia Bolesława mazowieckiego, a zatem - dodajmy - i przez państwo Łokietka. W liście do miast mowa jest o posłach, którzy ze strony adresatów mają być wysłani na Litwę dla zawarcia pokoju i z tym łączy się przyrzeczenie, iż będzie to pokój, jakiego nigdy chrześcijanie nie zaznali (quod christiani nunquam similem sentiebant). W liście do franciszkanów znajduje się prośba o skierowanie na Litwę jeszcze w tym samym roku czterech braci, którzy by znali języki polski, żmudzki i ruski, co mogłoby wskazywać nie tyle na potrzeby misyjne, ile na posługi o charakterze dyplomatycznym. W tymże liście jest przypomnienie o powstałych już kościołach w Wilnie i Nowogródku, które — jak wiadomo skądinąd - były właśnie w pieczy franciszkanów.

Godna uwagi jest arenga listu do miast, która w chrześcijańskiej otoczce ideowej wyraża — jak się wydaje — pogląd na władzę wielkoksiążęcą na Litwie. Oto jej treść: „Ponieważ wszystkie królestwa podlegają królowi niebieskiemu, Jezusowi Chrysusowi, tak jak forma w materii czy niewolnik w domu, a jedno z tych królestw my dzierżymy i chociaż jawimy się jako najmniejszy spośród wszystkich królów, jednak z łaski Bożej u siebie największy (in propriis maximus), gdzie mamy moc rozkazywać i rządzić, gubić i ocalać, zamykać i otwierać".

Drugi godny osobnej uwagi szczegół dotyczy pieczęci Giedymina. Należy tę sprawę tutaj podnieść, ponieważ — jak się wydaje - nie zawsze była dobrze rozumiana. Otóż listy zostały opatrzone pieczęcią. Jest to ta sama pieczęć, którą został uwierzytelniony list do Stolicy Apostolskiej. 
Tę to pieczęć Krzyżacy świeżo (nunc) wrzucili do ognia ku zniewadze Giedymina i zniewadze poselstwa, które poszło do papieża ${ }^{25}$. Informację tę rozumiano $\mathrm{w}$ taki sposób, że to list adresowany do głowy Kościoła został przez Krzyżaków przechwycony i jego pieczęć wrzucona do ognia. Stąd podnoszono wątpliwości, czy ów list w ogóle mógł do Awinionu dotrzeć. Ale taka interpretacja nie jest konieczna, bo zniszczona pieczęć mogła należeć do całkiem innego dokumentu, a jej spalenie oznaczać zniewagę także poselstwa do papieża. Dlatego wystawca jak gdyby się tłumaczył, że pieczętuje listy pieczęcią zlekceważoną przez Zakon, ale jest to ta sama pieczęć, którą uwierzytelniono list do papieża.

Wreszcie jest w tych dokumentach dość nietypowa, a zatem nieformularzowa formuła, odgrywająca rolę maledykcji. Właśnie przez swoją nietypowość zasługuje na uwagę, a w jednej jej części można by się dopatrzeć jakiejś kulturowej osobliwości. Otóż wszystkich, którzy w złej wierze działać będą przeciw temu pismu i jego pieczęci, z góry wystawca uznaje za zdrajców prawdy, czcicieli szatana, burzycieli wiary, kłamliwych heretyków, pozbawionych czci. I to jest właśnie rodzaj maledykcji, której wszakże towarzyszy w dokumencie adresowanym do dominikanów zapewnienie, że prędzej żelazo wejdzie czy też wtopi się w wosk i prędzej się $\mathrm{w}$ wodę zamieni, niż Giedymin cofnie swoje słowo, a zatem to, co oświadczył na temat chrystianizacji swego kraju.

Kolejne ogniwo, które chwytamy z dochowanych źródeł, dotyczy pokoju, jaki został zawarty w Wilnie w dniu 2 października 1323 r. między Giedyminem $\mathrm{z}$ jednej strony o Zakonem Inflanckim, arcybiskupem ryskim, jego kapitułą, biskupami Dorpatu i Ozylii oraz miastem Rygą z drugiej. Faktycznie był to pokój trójstronny, bo - jak wiadomo - arcybiskup z kapitułą i swoimi sufraganami oraz miasto Ryga pozostawały wcześniej $\mathrm{w}$ sporze $\mathrm{z}$ Zakonem i łączne ich wystąpienie z Zakonem wobec Litwy było wynikiem porozumienia. Omówiony już dokument rajców ryskich z 29 listopada 1322 r. wyraźnie zastrzegał, że Giedymin nie zawrze poza nimi pokoju z Zakonem. Zachowały się też trzy dokumenty tego pokoju: dokument Giedymina z 2 października oraz rewersały wysłanników Zakonu Inflanckiego i posłów kapituły z miastem Rygą, a nadto akt dodatko-

${ }_{25} \mathrm{~W}$ dokumencie do zgromadzeń dominikańskich: Licet Cruciferi, huius negotii causa, prescripti sigillum nostrum in contumeliam nostram igne cremaverunt, videbitur, ut a Deo inceptum extinguerent et oculos hominum obcecarent, tamen hanc cartam cum ipso sigillamus, prout sigillari fecimus litteras domini patris apostolici predilecti in certam credentiam et munimen. W dokumencie do zgromadzeń franciszkańskich: In cuius rei testamonium nostrum sigillum, quod domino apostolico et patri nostro sanctissimo misimus, quod nunc Cruciferi ad ignem proiecerunt, in contumeliam huius legationis, presentibus duximus apponendum. W dokumencie do miast: Presentem cartam conscribi iussimus et sigilli nostri appensione fecimus roborari, quia hoc scientes, quod idem sigillum domino nostro ac patri sanctissimo misimus et quidquid sibi litteraliter conscripsimus, servabimus illibatum. 
wy stanów inflanckich ${ }^{26}$. Odzwierciedlają one złożoność sytuacji. Dokumenty zostały spisane w języku niemieckim, a dokument Zakonu Inflanckiego zachował się w oryginale. Pokój jest więc faktem bezspornym. Przywiązywano do niego dużą wagę i w niespełna rok później został on zatwierdzony przez papieża, a tekst zawierający jego warunki przetłumaczono na język łaciński ${ }^{27}$. Do sprawy tego papieskiego zatwierdzenia wypadnie jeszcze powrócić, tu natomiast trzeba stwierdzić krótko, że pokój z 2 października 1323 r. przewidywał wolność poruszania się ludzi każdej ze stron w kraju kontrahenta, gwarantował odpowiedni wymiar sprawiedliwości, ludziom wolnym dawał prawo swobodnego osiedlania się u kontrahenta, a zbiegły człowiek niewolny miał być zwrócony, gdy się o niego upomniano. Gwarantowano sobie wzajemnie zwrot dóbr nieprawnie zagarniętych u każdej ze stron, zapewniono sobie wzajemnie swobodę handlu, a Giedymin przyrzekł stosować prawo ryskie względem przybywających na Litwę osadników. Miało ono być również stosowane wobec Litwinów przybywających do Inflant.

Trzeba w tym miejscu stwierdzić, że gdyby listy z 26 maja, a także wcześniejsze, mające za wystawcę Giedymina, zostały sfabrykowane w Rydze, jako środek nacisku na Zakon, z którym Ryga i jej arcybiskup pozostawały w sporze, to zawarty pokój należałoby uznać za sukces tej gry, która więc powinna się na tym zakończyć. Również patrząc na sprawę inaczej, tj. traktując te listy nie jako falsyfikaty, ale jako istotnie pisane $\mathrm{z}$ inspiracji $\mathrm{i}$ w imieniu Giedymina $\mathrm{z}$ krótkodystansowym instrumentalnym celem wywarcia presji na Zakon, trzeba by przyjąć, że 2 października 1323 r. cel ów w znacznym stopniu osiągnięto i dalsze zabiegi zmierzające do chrystianizacji Litwy byłyby już na tym gruncie niezrozumiałe. Był to co prawda dla Giedymina tylko sukces częściowy, bo w pokoju nie uczestniczył Zakon pruski, nie mniej groźny od inflanckiego.

Jak więc sprawa chrystianizacji Litwy rozwinęła się dalej?

Można by tu zatem nie brać pod uwagę listu papieża Jana XXII do króla francuskiego z 7 listopada 1323 r., donoszącego o zamiarze przyjęcia chrześcijaństwa przez Giedymina, ,który się tytułuje królem Litwy i Rusinów", bo wprawdzie czytamy w liście, że Giedymin świeżo (nuper) zwrócił się w tej sprawie do Stolicy Apostolskiej i prosił o legatów ${ }^{28}$, ale nie było to na pewno po zawarciu pokoju z Zakonem Inflanckim, a prawdopodobnie chodzi o pismo, o którym wiemy z dokumentów z 26 maja $1323 \mathrm{r}$.

Trzeba natomiast przytoczyć i omówić te dokumenty, które odzwier-

26 PreussUb $2 \mathrm{nr}$ 418, 419, 420, 421; LEC $2 \mathrm{nr}$ 693, 694; $6 \mathrm{nr} 3070,3071$.

27 PreussUb 2 nr 483; LEC 2 nr 707.

28 LEC $2 \mathrm{nr} 697$. 
ciedlają rozgłos, jakiego sprawa chrystianizacji Litwy nabrała i stała się przedmiotem sprzecznych opinii. W dniu 25 listopada 1323 r. Mikołaj, kustosz pruskiej prowincji franciszkanów, wraz z gwardianami tejże prowincji wystawili dwa dokumenty, znane $\mathrm{z}$ oryginałów: jeden adresowany do Stolicy Apostolskiej, a drugi ogólnie do świata chrześcijańskiego, w których stwierdzają, że ze strony niektórych konkurentów Zakonu Krzyżackiego powstały zarzuty, jakoby Zakon przeszkadzał „królowi Litwy” i jego ludziom przyjąć chrześcijaństwo. Mowa tu o listach wysłanych przez tego króla w różne części świata (per plures mundi partes), głoszących, że wraz ze swoim państwem pragnie się on ochrzcić i włączyć do społeczności chrześcijańskiej. Badacze nie kwestionują autentyczności owych listów, ale zwracają uwagę na to, że różni ludzie przybywający na Litwę stwierdzają nie tylko fikcyjność owych deklaracji, lecz wręcz znieważanie Boga w otoczeniu Giedymina czy też na Litwie. Biorą oni oczywiście w obronę Zakon, podkreślając jego zasługi, poświęcenie i szczerość intencji ${ }^{29}$.

Gdzieś około tego czasu musiały jednak powstać podejrzenia i zarzuty, że listy wysłane w imieniu Giedymina zostały sporządzone w Rydze, tamże opatrzone pieczęcią i przez Rygę kolportowane. Oskarżenie takie zostało ujęte, zapewne przez Zakon, w formę dokumentową i miało charakter publiczny. Dowiadujemy się o tym z pisma miasta Rygi ze stycznia 1324 r., adresowanego do Lubeki, a więc do miasta, które było jednym z głównych adresatów dwu listów Giedymina (25 I 1323 i $26 \mathrm{~V}$ 1323). Rajcy ryscy, odpierając zarzut, stwierdzają, że ze strony Zakonu wysłano już poselstwo do Giedymina, aby sprawdzić, czy istotnie od niego owe listy wyszły. Musiano mu okazać oryginal któregoś z tych listów, bo według tego samego świadectwa oświadczył on, że pieczęć jest jego, a artykuły zawarte $\mathrm{w}$ liście wyszły $\mathrm{z}$ jego ust (ex ore suo perlati). Zapytany, czy chce te artykuły podtrzymać, stwierdził w sposób wymijający, że pokój został zawarty, choć był przez Zakon naruszany. W tym samym liście znajdujemy wzmiankę o chrześcijańskim małżeństwie księcia mazowieckiego Wacława (Wańki) z córką Giedymina Elżbietą, które jeszcze przed 2 X 1323 zostało zawarte ${ }^{30}$.

Tymczasem w dniu 10 lutego 1324 r. papież Jan XXII, być może reagując na list lub listy Giedymina, ale przede wszystkim na skargi arcybiskupa ryskiego, wystosował pismo do wielkiego mistrza i mistrzów Zakonu Krzyżackiego, w tym do inflanckiej jego części, z zarzutem przeszkadzania w pracy misyjnej franciszkanom i dominikanom. Pod groźbą ekskomuniki nakazał zaprzestanie takich praktyk; zabronił uciskania duchownych i niszczenia kościołów, to jest właśnie tego, na co skarżył się

29 PreussUb 2 nr 429, 430.

so LEC 6 nr 3072; PreussUb 2 nr 443 (regest). 
w swoich listach Giedymin. Źródło to nie podlega żadnym podejrzeniom, bo zachowało się w Archiwum watykańskim ${ }^{31}$.

Z kolei bogatszy materiał do sprawy chrystianizacji Litwy znajdujemy $\mathrm{w}$ całym szeregu bull papieskich, wystawionych $\mathrm{w}$ dniu 1 czerwca 1324 r. i zachowanych w Archiwum watykańskim. Na uwagę zasługuje w tej serii przede wszystkim bulla adresowana do Giedymina ${ }^{32}$. Znajdujemy $\mathrm{w}$ niej informację, że Giedymin w dwu listach zwracał się do Stolicy Apostolskiej. Ponieważ w swojej odpowiedzi papież włączył się w tok myśli tych listów, pozwala nam się zorientować $\mathrm{w}$ ich treści. Jeden $\mathrm{z}$ nich to najwyraźniej ten nie datowany, który znamy i który datowano albo na maj 1323 r., albo na koniec 1322 r. Drugi w swojej treści wyraźnie się odróżnia i to jest brakujące ogniwo całej sprawy. Złożył w nim Giedymin jak gdyby wyznanie wiary, przyjmując, że jeden jest Bóg w trzech osobach, że papież został przez Boga ustanowiony pasterzem i zarządcą tych wszystkich, którzy mają być zbawieni (salvandorum omnium), że wreszcie to, co zostanie przez Kościół lub przez papieża zawiązane lub rozwiązane, pozostanie $\mathrm{w}$ mocy na ziemi i w niebie. Były w tym liście inne jeszcze mile słowa, które dla zwięzłości odpowiedzi zostały w piśmie papieskim pominięte. Jest tu jeden element odniesiony przez papieża do listu pierwszego, nieznany nam z tekstu, który za pierwszy list uważamy. A mianowicie, że Giedymin prosił, aby Stolica Apostolska powierzyła misję na Litwie arcybiskupowi ryskiemu i specjalnemu legatowi.

Przechodząc do tzw. dyspozycji, papież wyraża radość z gotowości Giedymina przyjęcia chrześcijaństwa, a potem daje wykład na temat, czym jest Kościół Boży. Określa go jako dom wybrany przez Boga. Przytacza myśl, że jedna ma być owczarnia i jeden pasterz. Tę to owczarnię Chrystus odkupił swoją krwią. Dalej pisze papież o przekazaniu przez Chrystusa władzy w Kościele św. Piotrowi, do którego po zmartwychwstaniu powiedział: „paś owce moje” (pasce oves meas) i potem ,tobie dam klucze do Królestwa niebieskiego" (tibi dabo claves Regni celorum). Przypomina, że kto pójdzie za nauką Chrystusa, zostanie zbawiony, a kto nie, będzie potępiony. Od tego wykładu przechodzi papież do sprawy przyjęcia chrześcijaństwa przez Giedymina i zapowiada wysłanie na Litwę swoich legatów, którzy już zostali wyznaczeni. Są nimi Bartłomiej biskup Aletu i Bernard opat klasztoru św. Teofryda w Puy. Podnosi ich uczoność i chwalebność obyczajów i podkreśla, że powinni oni dokonać aktu chrztu i nauczać wiary. Z kolei papież przechodzi do sprawy Zakonu, zapowiadając dopełnienie sprawiedliwości i zapewnienie pokoju, bez którego nie może być godnie czczony stwórca pokoju (pacis auctor). Przyczynić się mają do tego, oprócz papieża stawiającego się tu w roli ojca, także

${ }^{81}$ LEC $2 \mathrm{nr}$ 700; Theiner $1 \mathrm{nr} 279$; PreussUb $2 \mathrm{nr} 450$ (regest).

32 Theiner $1 \mathrm{nr} 293$ (tekst); LEC $2 \mathrm{nr}$ 703; PreussUb $2 \mathrm{nr} 461$ (regest). 
kardynałowie i szczególnie owi legaci. W ich osobach przyjmie Giedymin jak gdyby samego papieża i tak powinien ich traktować, aby swobodnie mogli nauczać (ut evangelisare libere valeant). Apeluje wreszcie do niego, aby dla mieszkających pod jego władzą katolików był pius et misericors, benevolus et benignus.

W kolejnej bulli z tej samej daty, adresowanej do obu legatów, przedstawia papież jak gdyby program czy też instrukcję podjętej legacji o charakterze misyjnym ${ }^{33}$. W bardzo obszernym tekście przedstawia najpierw te okoliczności, które do legacji doprowadziły, a więc powtarza cały wywód z poprzedniej bulli o dwu listach Giedymina do Stolicy Apostolskiej i ich treści, akcentując w sposób szczególny niektóre elementy. Trzeba tu podnieść, że drugi list władcy Litwy został według tej bulli przesłany do Awinionu po upływie pewnego czasu (post aliqualem decursum temporis). Podkreślono tu, że Giedymin nie zwalczał dotąd chrześcijańskiej wiary, ale się bronił od wrogów, tak jak to czynią inni władcy chrześcijańscy; nie chciał burzyć wiary chrześcijańskiej (fidem destruere christianam), skoro dopuszczał do swego kraju dominikanów i franciszkanów, aby chrzcili i nauczali. Tak więc wchodzili legaci na glebę przeoraną już pługiem Bożym (divino vomere), na której mieli zasiać ziarno łaski (semen graciae). Mieli przyjmować, chrzcić i włączać do owczarni wiernych (recipere, baptizare et ovili fidelium agregare).

Z kolei bulla precyzuje zakres władzy duszpasterskiej i kanonicznej legatów. Biskup Bartłomiej zachowywał prawa biskupie o charakterze szczególnym. Mógł uwalniać od wielkiej ekskomuniki tych, którzy porzucili wiarę. Mógł przyjmować schizmatyków na łono Kościoła katolickiego, przywracać prawa kapłańskie duchownym, którzy ze stanu duchownego odeszli, odpuszczać grzechy duchownym, którzy zabijali, jeżeli wynagrodzą szkody i krzywdy, przywracać do praw kapłańskich duchownych, którzy w stanie apostazji sprawowali służbę Bożą jako schizmatycy, zwalniać od ślubów dotyczących zamorskich pielgrzymek, udzielać dyspensy schizmatykom, którzy by przeszli na katolicyzm, a mieli żony w trzecim lub czwartym stopniu pokrewieństwa, przyjmować do Kościoła tych, którzy uprawiali symonię, jeżeli zadośćuczyniliby poszkodowanym. Legaci mieli moc przywracania i zakładania metropolii i biskupstw, udzielania odpustów przy okazji konsekracji kościołów i uroczystych świąt do roku i 40 dni, powoływania metropolitów, biskupów i zarządców kościołów, a także cedowania na nich własnych uprawnień, zmiany uposażeń, dyspensowania dominikanów i franciszkanów co do przenoszenia się i uposażenia. Do decyzji Stolicy Apostolskiej zostały zastrzeżone tylko te ekskomuniki, które łączyły się ze wspieraniem przez chrześcijan saracenów, a więc

33 Theiner $1 \mathrm{nr} 290$ (tekst); PreussUb $2 \mathrm{nr} 462$ (regest). 
wysyłaniem im broni lub towarów na szkodę chrześcijaństwa, szczególnie Ziemi Swiętej.

W osobnej bulli adresowanej do Giedymina przesyła papież wykład artykułów wiary ${ }^{84}$. Jak gdyby w obawie, że na kresach Kościoła łacińskiego i na jego styku z Kościołem wschodnim łatwo może dojść do odchyleń od dogmatów katolicyzmu, zaangażował własny autorytet w ów wykład wiedzy rudymentarnej, aby w razie potrzeby uchylić wątpliwości bez uciekania się do długich dyskusji i wyjaśnień. Nie byłoby celowe referowanie tej sprawy w szczegółach, ale godzi się spostrzec, że całość programu chrystianizacji Litwy została gruntownie nie tylko od strony organizacyjnej przez Stolicę Apostolską przygotowana.

Z kolei trzeba wspomnieć kilka bull papieskich, w które zostali opatrzeni legaci i które miały im zapewnić jak najlepsze warunki działalności misyjnej. W jednej z nich wyznaczył papież owym legatom dietę w wysokości 8 florenów (dziennie) dla biskupa Bartłomieja i 5 florenów dla opata Bernarda. Mogli je egzekwować u dostojników kościelnych z biskupami i arcybiskupem włącznie, na Zakonie Krzyżackim i na innych zgromadzeniach, nawet przy użyciu cenzur kościelnych ${ }^{35}$. W osobnej bulli uzyskali prawo wymuszania na dominikanach i franciszkanach pomocy misyjnej, pomocy w wyznaczaniu tłumaczy itp., znów z możliwością użycia cenzur ${ }^{36}$. Inna bulla zezwalała im w razie potrzeby odprawiać nabożeństwa nocą lub zezwalać na to towarzyszącym im kapłanom ${ }^{37}$, w jeszcze innej uzyskali prawo odprawiania nabożeństw na obszarach obłożonych interdyktem, jeżeli sami nie daliby powodu do tej cenzury kościelnej; nie należało wszakże bić w dzwony i dopuszczać do nabożeństw osób ekskomunikowanych ${ }^{38}$. W osobnej bulli z tej samej daty papież obłożył ekskomuniką ipso facto tych wszystkich, którzy by przeszkadzali legatom w dziele misyjnym. Ich ziemie podpadały równocześnie pod interdykt. Zwolnienie od tych cenzur zostało zastrzeżone dla Stolicy Apostolskiej, wyjąwszy articulum mortis, kiedy zwalniać mogli osobiście legaci ${ }^{39}$. W osobnej wreszcie bulli uzyskali legaci prawo pozywania przed Stolicę Apostolską wszystkich przeszkadzających ich dziełu ${ }^{40}$.

Mamy jeszcze dwa pisma Jana XXII adresowane do czynników zewnętrznych. Jedno poleca legatów arcybiskupom, biskupom, opatom i przeorom różnych zgromadzeń zakonnych, zobowiązując ich, aby tym, którzy podjęli magna et ardua negotia ecclesiae Romanae et fidei ortodoxae,

${ }^{34}$ Tekst zachowany $w$ oryginale: Theiner $1 \mathrm{nr}$ 298; PreussUb $2 \mathrm{nr} 463$ (regest).

${ }_{35}$ Theiner $1 \mathrm{nr} 294$ (tekst); PreussUb $2 \mathrm{nr} 466$ (regest).

${ }^{86}$ Theiner $1 \mathrm{nr} 295$ (tekst); PreussUb $2 \mathrm{nr} 465$ (regest).

37 Theiner $1 \mathrm{nr} 300$ (tekst); PreussUb $2 \mathrm{nr} 467$ (regest).

38 Theiner $1 \mathrm{nr} 299$ (tekst); PreussUb $2 \mathrm{nr} 468$ (regest).

39 Theiner $1 \mathrm{nr} 291$ (tekst); PreussUb $2 \mathrm{nr} 470$ (regest).

40 Theiner $1 \mathrm{nr} 292$ (tekst); PreussUb $2 \mathrm{nr} 471$ (regest). 
wypłacali ową określoną już dietę ${ }^{41}$. Druga, adresowana specjalnie do Zakonu Niemieckiego, informuje o liście Giedymina, wyrażającym gotowość do poznania i przyjęcia chrześcijaństwa (ad cognoscendam et percipiendam lucem catholicae veritatis), dokonuje prezentacji legatów, wspomina o skargach władcy Litwy na Zakon i o jego zabiegach o sąd papieski w sporze z Zakonem, a w końcu zabrania wszelkich wrogich działań w stosunku do litewskiego sąsiada; wręcz przeciwnie - wzywa do przychylności względem niego (immo teneri vos volumus cum eodem rege) ${ }^{42}$.

Kolejnym przedsięwzięciem Jana XXII było zatwierdzenie pokoju między Giedyminem, arcybiskupem ryskim i Zakonem Inflanckim, zawartego w dniu 2 października $1323 \mathrm{r}$. Był to wynik zabiegów specjalnego poselstwa miasta Rygi, które - jak wiadomo - zostało do układu pokojowego włączone. Dokument papieski w tej sprawie, wystawiony 31 sierpnia 1324 r., transumował w pełnym tekście akt Giedymina oraz rewersał posłów zakonnych, przetłumaczone zapewne wówczas na język łaciński. Przy tej okazji papież stwierdził to, co wiemy już z bull z 1 czerwca 1324 r., że Giedymin pragnie się nawrócić na wiarę katolicką i przyjąć chrześcijańskie obyczaje (ad veritatem converti desiderat fidei orthodoxae et professionis doctrina catholicae et moribus imbui christianis). Powtarza też o Giedyminie, że od dzieciństwa słyszał on od swoich przodków, że papież jest ojcem i panem wszystkich jego ludzi (quod Romanus pontifex erat pater et dominus omnium suorum). Mowa tu także o tym, że Giedymin, rozpoznawszy przy dokumencie przez siebie wystawionym ( 2 X 1323) swoją pieczęć, stwierdził, iż wszystkie artykuły w nim zawarte pochodzą od niego (de cordis sui consciencia). Takie oświadczenie złożyć musieli w Stolicy Apostolskiej posłowie Rygi i oni zapewne zwracali się do Giedymina z zapytaniem, czy pragnie trwać przy przyjętych warunkach pokoju. Mowa tu wreszcie o legacji Bartłomieja i Bernarda ${ }^{48}$.

Wnet wspomniani legaci papiescy udali się w drogę i skierowali się do arcybiskupa ryskiego. Byli tu $\mathrm{w}$ każdym razie $\mathrm{w}$ październiku $1324 \mathrm{r}$. Działalność swoją rozpoczęli zapewne od zbadania stosunków Litwy z Zakonem. Dnia 20 października 1324 r. wystawili dokument, adresowany do Zakonu Krzyżackiego w Prusach, w którym - dopiero co przybywszy (nuper) - informowali, że akceptują warunki pokoju zawartego między „klerem, ludem i wasalami miasta, diecezji i prowincji ryskiej oraz niektórymi braćmi" Zakonu z jednej strony a Giedyminem z drugiej; zalecali mistrzowi i braciom pruskim włączenie się do tego pokoju, grożąc w każ-

\footnotetext{
gest).

41 Theiner $1 \mathrm{nr} 296$ (tekst); LEC $2 \mathrm{nr} 705$ (tekst); PreussUb $2 \mathrm{nr} 464$ (re-

42 Theiner $2 \mathrm{nr} 297$ (tekst); LEC $2 \mathrm{nr} 704$ (tekst); PreussUb $2 \mathrm{nr} 469$ (regest).

${ }^{43}$ LEC 2 nr 707 (tekst); PreussUb 2 nr 483 (regest).
} 
dym razie ekskomuniką, gdyby go naruszyli ${ }^{44}$. Sprawę traktowali jako procesową, a wezwanie do Zakonu równocześnie jako pierwsze, drugie, trzecie i ostateczne, a więc nie pozostawiające już zwłoki na przedstawienie jego stanowiska. W ten sposób na plan pierwszy ich przedsięwzięcia wysunęła się sprawa polityczna: neutralizacja czy tė̇ związanie warunkami pokojowymi pruskiej części Zakonu, na czym niewątpliwie zależało przede wszystkim Giedyminowi, ale zapewne także Rydze i ryskiej hierarchii kościelnej.

Jeszcze 12 listopada 1324 r. wyszła z Awinionu bulla Jana XXII, zezwalająca prowincjałowi saskiej prowincji franciszkanów w Prusach założyć na Litwie dwa klasztory franciszkańskie, zapewne w porozumieniu z Giedyminem, a nadto jeden w Rewalu ${ }^{45}$, ale już wcześniej musiały dochodzić z Litwy niepokojące głosy, że Giedymin odstąpił od zamiaru przyjęcia chrześcijaństwa i chrystianizacji swojego kraju. Na początku listopada wysłali legaci swoje poselstwo do Giedymina. Złożona przez nich relacja, jeszcze w listopadzie 1324 r., jest dla całej sprawy przyjęcia chrześcijaństwa przez Litwę pod panowaniem Giedymina źródłem pierwszorzędnego znaczenia i wymaga bliższej uwagi ${ }^{46}$.

Posłowie przedstawiają się jako wykonawcy zleceń znanych nam już dobrze legatów Stolicy Apostolskiej, arcybiskupa ryskiego i jego sufraganów oraz miasta Rygi. Wyraźnie więc widać, jakie czynniki zaangażowały się w sprawę misji na Litwie. Przybyli oni do Giedymina, niewątpliwie do Wilna, w sobotę po Wszystkich Swiętych, która w 1324 r. wypadła 3 listopada. Zostali przyjęci przez niego i jego radę jeszcze tego samego dnia w godzinach wieczornych. Polecił im jednak tylko udać się na spoczynek. Następnego dnia rano poszli na mszę do franciszkanów i jeszcze przed mszą pytali brata Mikołaja, czy Giedymin obstaje przy tym, co deklarował papieżowi i całemu światu, skąd mamy prawo wnosić, że były już co do tego wątpliwości. Usłyszeli, że władca Litwy zmienił swój zamiar. Z kolei po mszy rozmawiali z braćmi Henrykiem i Bertoldem ze zgromadzenia franciszkańskiego, którzy potwierdzili, że Giedymin miał dobry zamiar, ale istotnie zmienił go pod wpływem innych (aliis intervenientibus).

Tymczasem jeszcze w trakcie mszy Giedymin wezwał brata Mikołaja, a po mszy również Bertolda i Henryka. Wysłannicy natomiast udali się na posiłek. Wnet poproszono ich do Giedymina. Byli zaniepokojeni, gdy spostrzegli, że znów nie przyjmuje ich sam, ale w towarzystwie około 20

44 Dokument zachowany w oryginale; LEC $2 \mathrm{nr} 708$ (tekst); PreussUb $2 \mathrm{nr} 487$ (obszerny regest przytaczający znaczną część tekstu).

45 Monumenta Poloniae Vaticana, wyd. J. Ptaśnik, t. 3, Kraków 1919, nr 177.

46 LEC 6 nr 3073 (tekst); PreussUb 2 nr 491 (regest). Tekst zachowany w formie konceptu kancelaryjnego i jego współczesnego odpisu. 
osób. Dopuszczeni do głosu, zaczęli mówić o przybyciu legatów Stolicy Apostolskiej, o wszczętym postępowaniu przeciw Zakonowi, o zwrocie zagarniętych przez Zakon ludzi i rzeczy, co bardzo Giedymina ucieszyło i okazał wysłannikom swoją wdzięczność. Potem mu przypomnieli o liście, wysłanym do rajców ryskich, a on zaznaczył, że nie mógł się posłużyć własnymi wysłannikami do Stolicy Apostolskiej, bo kiedy w roku poprzednim skierował tamże swojego posła, to został on przez Krzyżaków schwytany w drodze, znieważony i źle traktowany. Prosił był zatem miasto Rygę, aby ono posłało kogoś z jego sprawami do papieża. Owym posłem był jeden z uczestników przybyłego obecnie do Wilna poselstwa legatów, a wręczenia papieżowi pisma władcy Litwy dokonał on wraz z przebywającym w kurii arcybiskupem ryskim. Papież niemal natychmiast zwołał kardynałów, ale nie mógł wysłać swoich legatów zaraz, bo nie miał odpowiednich ludzi. Właśnie teraz ich posłał, aby dokonali nawrócenia, o które zabiegali i Giedymin, i jego poprzednicy. Tak więc dowiadujemy się o udziale miasta i arcybiskupa, zarówno w nawiązaniu przez Litwę kontaktu z Awinionem, jak i w dalszym biegu tej sprawy.

Po tym przypomnieniu przez posłów owych antecedencji zwrócił się Giedymin do nich z zapytaniem, czy wiedzą, o czym on pisał do papieża, do miast i do arcybiskupa. Odpowiedzieli, że intencją listów był jego chrzest i włączenie się do społeczności chrześcijańskiej. Odparł, że nie kazał tego pisać, a jeżeli brat Bertold tak napisał, to spadnie to na jego głowę. „Lecz jeżeli kiedykolwiek miałem taki zamiar, to niech mnie diabeł ochrzci" - miał dodać brutalnie. Ale oświadczył zarazem, że papieża i arcybiskupa nadal chce mieć za swoich ojców, ponieważ są od niego starsi. Gdyby mu byli równi wiekiem, uważałby ich za braci, a gdyby byli młodsi, to za synów. Powiedział, że chce, aby chrześcijanie czcili Boga według swego zwyczaju, Rusini według swego, Polacy według swego, zaś „,my Litwini czcimy Boga stosownie do rytu naszego, a wszyscy mamy jednego Boga". Słowem potwierdził treść listu z wyjątkiem przyjęcia chrześcijaństwa, ponieważ nie chciał się ochrzcić (quia nollet baptizari).

W dalszym wywodzie powiedział: „Cóż mówicie mi o chrześcijanach? Gdzie znajduje się większa nieprawość, większa niesprawiedliwość, gwalt, zepsucie i lichwa, jak u chrześcijan, a szczególnie u tych, którzy są uważani za religijnych, jak Krzyżacy, dopuszczający się wszelkiego zła; zniewalali biskupów, więzili ich i trzymali w nędzy, jak długo chodziło o to, aby się z nimi układali według ich woli; niektórych wygnali, księży i osoby duchowne pozabijali, miastu Rydze poczynili wielkie szkody i od samych zawiązków tego chrześcijaństwa nie dotrzymywali, cokolwiek pod przysięgą przyrzekli. W szczególności w roku ubiegłym, gdy tu przebywali posłowie panów ziemi, za zgodą ich wszystkich, nie przymuszeni, uczynili pokój dla całego chrześcijaństwa i przysięgą go utwierdzili i na jego 
znak całowali krzyż, a natychmiast potem, cokolwiek umocnili przysięgą, niczego w ogóle nie dotrzymali, ponieważ zabili moich posłów, których wysłałem dla potwierdzenia pokoju, tak jak to uzgodniliśmy, i nie tylko ich, ale wielu innych i wielokrotnie zabijali, więzili, brali w okowy i w ciężkich warunkach trzymali; i dlatego nie wierzę w żadne ich przysięgi".

Następnego dnia posłowie wysłuchali mszy u franciszkanów. Kiedy już byli w swojej kwaterze i spożyli posiłek, przyszli do nich wysłannicy Giedymina z zapytaniem, czy mocodawcy tychże posłów, czy tė̇ szerzej strona chrześcijańska pragnie zachować pokój. Jeżeli tak, to on też go utrzyma, a jeżeli nie, to jest gotów dać swoim przeciwnikom nauczkę (ipse vellet eis satis dare ad munus). Po krótkiej naradzie posłowie odpowiedzieli, że nie wiedzą, jakie będzie stanowisko w tej sprawie legatów i arcybiskupa, dlatego zaproponowali, aby Giedymin wysłał z nimi swego posła czy swoje poselstwo. Musieli wszakże na żądanie Giedymina zaręczyć głową, że poselstwo bezpiecznie pojedzie i wróci.

W kolejny dzień odbyło się u franciszkanów (in hospitio fratrum minorum), w obecności tychże posłów, a także dominikanów (fratrum maiorum), indagowanie w sprawie treści owych pism Giedymina. Był przy tym tłumacz oraz jakiś pełnomocnik władcy Litwy nazwany advocatus. Brat Henryk przyznał się, że pisał to pismo, z którym później został w poselstwie wysłany i które Krzyżacy zatrzymawszy go uszkodzili. Z kolei pytano Bertolda, czy on pisal, że Giedymin chce się ochrzcić. Nie ukrywał, że pisał ostatni list, który został wysłany przez rajców ryskich, ale nie było $\mathrm{w}$ nim niczego, co nie wyszłoby $\mathrm{z}$ ust Giedymina (ex ore regis). W szczególności znajdowała się w nim deklaracja, że Giedymin chce być papieżowi posłuszny, wejść do społeczności chrześcijańskiej, przyjąć chrześcijan do swego państwa i w krótkim czasie dopełnić powinności wiary (fidem Christi breviter ampliare). Była też mowa o tym, że dotychczas tkwił w błędzie. „Adwokat” Giedymina pytał specjalnie, czy nic nie pisał o chrzcie, na co zgodnie odpowiedzieli i Bertold, i Mikołaj, że to, co napisano, oznaczało właśnie chęć przyjęcia chrztu. Przy tym Mikołaj złożył winę na Bertolda. Na tym dzień upłynął, a w następnym Giedymin przysłał do posłów swego ,adwokata”, żeby sekretnie z nimi porozmawiał, wtajemniczając ich, że Giedymin sam tej rozmowy odbyć nie może z powodu Tatarów, którzy stanowili w tym względzie jakąś przeszkodę; posłowie najwyraźniej uznali ją za upozorowaną. Odbyła się rozmowa, w której ci ostatni informowali m.in. o pełnomocnictwach legatów i pytali, czy Giedymin wyśle do nich swoje poselstwo. Usłyszeli w odpowiedzi, że tak, ale do tego nie doszło.

Tak wygląda relacja w wersji, która zapewne miała mieć charakter oficjalny. Ale na drugiej stronie pergaminu znajduje się jej część jak gdyby poufna. Piszą tutaj posłowie, powołując się na źródło sekretne, że 
Krzyżacy (fratres de Pruscia) przekupili podarkami możnych żmudzkich, aby powstali przeciw Giedyminowi i przy ich poparciu go obalili, gdyby się ochrzcił. Groźby takie padały pod adresem Giedymina często, także ze strony Rusinów. Informacji tych dostarczyli Henryk i Bertold, a zatem franciszkanie. Z kolei franciszkański towarzysz dominikanina Mikołaja obwinił go o to, że odradził Giedyminowi przyjęcie chrztu za pośrednictwem arcybiskupa, który był słaby, skoro przez 12 lat siedział w Awinionie i nie załatwił własnych spraw, a sugerował inne pośrednictwo, np. króla węgierskiego lub czeskiego.

Posłowie legatów na własną rękę wzięli na spytki niejakiego Hennekina, który był tłumaczem władcy Litwy i przekazywał Bertoldowi to, czemu on nadawał formę pisaną. Zaklinany na wiarę i sąd ostateczny, wyjawił, pod zastrzeżeniem utrzymania sprawy w tajemnicy spowiedzi, że istotnie Giedymin mial zamiar przyjąć chrześcijaństwo, nie wiedział jednak, dlaczego i $\mathrm{w}$ jakich okolicznościach od zamiaru tego odstąpił. Widział w tym działanie szatana (sed diabolus suum semen seminavit). W tej tajnej części jeszcze posłowie relacjonowali to, czego dowiedzieli się znów od pewnego franciszkanina, przy czym źródłem informacji była teraz pewna kobieta $\mathrm{z}$ otoczenia żony Giedymina. Miała ona zaznać, że Giedymin, po wyjściu od niego przybyłych z Rygi posłów, udał się ze swoim krewniakiem Eurodonem do sypialni i tam gorzko płakał, czyniąc przy tym przerwy. Powtarzał to jakoby nadal co noc po trzykroć.

Zreferowany tutaj przekaz jest wyraźnie tendencyjny: antykrzyżacki $\mathrm{i}$ antydominikański, ale $\mathrm{w}$ rzeczy zasadniczej nieprawdopodobny nie jest. Nie ma powodu podejrzewać, że plan chrystianizacji Litwy przez Giedymina w obrządku zachodnim był tylko mistyfikacją wytworzoną przez franciszkanów i Kościół ryski w jego walce z Zakonem. Byłoby nawet dziwne, gdyby władca tej miary, co Giedymin, nie dostrzegał wagi tej sprawy, a tym bardziej, aby przez dwa lata knuto poza jego plecami coś, co bez niego i tak odbyć się nie mogło. Nie da się także przyjąć poglądu, że jeżeli plan ten rodził się i dojrzewał za wiedzą i zgodą Giedymina, to był to tylko manewr taktyczny, mający mu zapewnić pokój na zachodzie, aby mógł skutecznie realizować swoją politykę wschodnią. Giedymin w swojej polityce nie był bynajmniej tak jednostronny, o czym świadczą jego rodzinne powiązania zarówno z Piastami mazowieckimi, jak też $\mathrm{z}$ Władysławem Łokietkiem. Wynikające $\mathrm{z}$ omówionego przekazu motywy odstępstwa od planu chrystianizacyjnego, raczej te podane poufnie niż 
oficjalne, a więc opór zwłaszcza możnych żmudzkich i ruskich, wspomagany dyskretnie przez Zakon, jest całkowicie przekonywający. Przekaz ujawnia jakże typową grę dyplomatyczną: unikanie osobistej rozmowy z posłami, zasłanianie się niebezpieczeństwem tatarskim, akcentowanie tego, że nigdzie Giedymin nie deklarował się co do chrztu, a wreszcie szukanie winnych wśród tych, którzy akta redagowali. Jakże to typowy dla okoliczności sposób postępowania. Nie mogła być oparta na samej mistyfikacji klątwa, którą w kwietniu 1325 r. rzucił na Zakon Inflancki arcybiskup ryski Fryderyk, tak czynny w całej omówionej sprawie, pod wyraźnym zarzutem uniemożliwienia chrystianizacji Litwy ${ }^{47}$.

\section{VERSUCHE DER CHRISTIANISIERUNG LITAUENS ZUR ZEIT GIEDYMINS}

\section{Z u s a m m e f a s s ung}

Der Autor befaßt sich mit zwei Episoden der Bemühungen um die Christianisierung Litauens, die mit der Herrschaft eines der Hauptorganisatoren des Litauischen Staats, Giedymin (1315-1341), verbunden sind. Die erste Episode lernen wir aus der Bulle des Papstes Johannes XXII kennen, die 1317 an den erwähnten Herrscher gerichtet war und sich lediglich der weltanschaulichen Argumentation bediente, wobei unbekannt ist, wer den Anstoß zu diesem Vorhaben gab. Es gibt ein wichtiges Anzeichen dafür, daß Polen eine solche Rolle spielen konnte. Die zweite Episode fällt in die Jahre 1322-1324 und ist der Hauptgegenstand der Erwägungen des Autors. Erklärt wird sie von einem umfangreichen Briefwechsel wie Schreiben Giedymins an den Heiligen Stuhl, an die Hansestädte, an die Franziskaner und die Dominikaner der sächsischen Provinz sowie von einigen Briefen an Giedymin, darunter einem Brief Johannes XXII, und einer ganzen Reihe von Dokumenten, die von diesem Papst im Zusammenhang mit einer speziellen Gesanditschaft ausgestellt wurden, die im Auftrag des Heiligen Stuhls in Litauen Missionsaufgaben erfüllen sollte (1324). Wir verfügen auch über einen Bericht über den Verlauf der ganzen Angelegenheit, verfaßt gegen Ende des Jahres 1324 von der von den dazumal in Riga weilenden päpstlichen Legaten an Giedymin gesandten Delegation.

Die Angelegenheit war bereits mehrmals Gegenstand von Forschungen, und ihre Wiederaufnahme ist damit begründet, daß sie noch immer kontrovers ist. Schon in Kreisen des Kreuzritterordens erhoben sich Stimmen, die Briefe Giedymins, genauer gesagt die in seinem Namen geschriebenen, seien Falsifikate. Diese Anschauung vertraten im 19. Jh. einige deutsche Forscher. In der polnischen Historiographie wurde (1896) ihre Authentie bewiesen, der Vorwurf der Fälschung wiederholte sich jedoch wiederum in den zwanzig Jahren zwischen den beiden Weltkriegen und blieb noch nach dem Kriege offen (K. Forstreuter, H. Spliet).

47 LEC 2 nr 837 (tekst); PreussUb 2 nr 502 (regest). 
Der Autor der vorliegenden Arbeit steht auf dem Standpunkt, daß ein so großes Christianisationsvorhaben nicht ohne Wissen und Zustimmung Giedymins unternommen und durchgeführt werden konnte. Er stellt in seinen Ausführungen der Reihe nach den Inhalt und den Sinn der einzelnen Schreiben dar, aus denen die völlige Kohärenz der einzelnen Glieder hervorgeht, und die Tatsache, daß die Briefe Giedymins micht im Original erhalten blieben, ist kein ausreichender Beweis dafür, daß es sich um Falsifikate handle. Die Resignation des Herrschers Litauens von dem Plan der Christianisation im Jahre 1324 ist leicht verständlich, wenn man den Widerstand in den Kreisen der eigenen Regierungselite bedenkt, der vom Orden selbst geschickt geschürt wurde. Es gibt auch keinen Grund zu der Annahme, daß jener Plan nur ein taktisches Manöver Litauens war, das ihm Frieden im Westen und freie Hand in der Ostpolitilk schaffen sollte, denn zweifelsohne legte gerade in den Jahren jener Christianisationsversuche Giedymin rege Aktivität an den westlichen Grenzen seines Landes an den Tag. 